\title{
Mononuclear Fe(III), Cr(III), Co(II) Metal Complexes Based on Azo-Anthraquinone Moieties: Synthesis, Characterizations and Antibacterial Activities
}

\author{
E. YILDIZ ${ }^{\mathrm{a}^{*}}$, M. KELES ${ }^{\mathrm{a}}$, A. KAYA ${ }^{\mathrm{b}}$ and S. DINCER ${ }^{\mathrm{b}}$

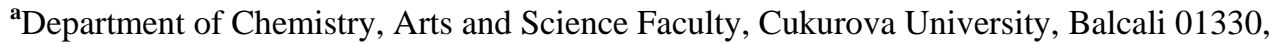 \\ Adana, Turkey \\ ${ }^{\mathbf{b}}$ Department of Biology, Arts and Science Faculty, Cukurova University, Balcali 01330, \\ Adana, Turkey \\ eeyildiz@cu.edu.tr
}

Received 16 August 2012 / Accepted 19 September 2012

\begin{abstract}
The coordination properties of anthraquinone ligands bearing $N$-heterocyclic coordination sites to divalent cobalt and trivalent iron and chromium metal complexes have been described and characterized as mono and binuclear complexes. Although 4-(2'-amino benzene sulfonic acid)azo(2' '- $N$-(4', ',6' '-dichloro-s-triazine)benzene-5' '-( $\beta$-sulfatoetylsulfonyl)-2-methylanthraquinone was found to form complexes having a ligand to the metal ratio of 2:1 with ferric and cobalt ions, 4(2'-amino benzene sulfonic acid)azo-(2' ' $N$-(4',',6','-dichloro s-triazine) naphtaline-5' '-sulfonic acid)-2-methyl anthraquinone gave a complex in a molar ratio of about 1:1 with Fe(III). Spectral results showed that the complexes have octahedral geometry. Antibacterial data showed that the complexes have medium antimicrobial activity against Staphylococcus aureus and clinical isolates strains.
\end{abstract}

Keywords: Anthraquinone, Antibacterial Effect, Azo, Metal Complex, s-Triazine

\section{Introduction}

Heterocyclic based azo compounds have been employed for the synthesis of dyes there remains much scope for the design and development of new chromophores with the coupling components ${ }^{1}$. Anthraquinone and azo derivatives are not only used for dyeing industry ${ }^{2}$ but also semiconductor lasers ${ }^{3}$, sensor molecules for the $\mathrm{Mg}^{2+}$ ion $^{4}$, electrochromism ${ }^{5}$, nonlinear optical elements and printing system ${ }^{6}$.

In recent decades, scores of new antimicrobial agents have been invented to substitute antimicrobial dyes including anthraquinone and azo groups. Cationic anthraquinone dyes, quaternary ammonium salts, demonstrate the excellent antimicrobial ability against both gram-negative and gram-positive bacteria in aqueous solution ${ }^{7-8}$. 
In the present paper, we report potential bidentate ligands bearing $\mathrm{N}-\mathrm{H}$ bridge binding azo and anthraquinone moieties, their metal complexes with iron(III), chromium(III) and cobalt(II) chlorides, which are the last part of the series of our previous work ${ }^{9}$. Disc diffusion method was used to determine the antibacterial activities of the synthesized compounds.

\section{Experimental}

1-Amino-4-bromo-2-methyl anthraquinone (98.8\%) used as an initial synthetic material, 2,4,6-trichloro-1,3,5-triazine and primer aromatic amines (2'-amino benzene sulfonic acid, 4-p-( $\beta$-sulfatoetyl sulfonyl)aniline, 5'-amino naphthaline-3'-sulfonic acid) used as the coupling component in the synthesis of the azo dyes were purchased from Aldrich Chemical Co. and was used without further purification. All other chemicals and solvents were of analytical grade and were used as received.

\section{Instruments}

FT-IR spectra was recorded on a Perkin Elmer RX I spectrometer as $\mathrm{KBr}$ disc, electronic spectra on Model Shimadzu UVG-54 spectrophotometer in the range 200-400 nm. ${ }^{1} \mathrm{H}-\mathrm{NMR}$ spectra was recorded on a Bruker/XWIN-NMR (400 MHz). UV-Vis spectra were measured on Perkin Elmer Lampda 25 Spectrometer. The metal percents were calculated according to the results of AAS Perkin Elmer Analyst-400. The magnetic measurements were carried out by the Gouy method, Sherwood Scientific Cambridge MS No:MK 1 using $\mathrm{CuSO}_{4} \cdot 5 \mathrm{H}_{2} \mathrm{O}$ as calibrant.

\section{Preparation of the ligands and coupling component}

Diazonium salts were synthesized and 1-amino-4-(amino- $p$-( $\beta$-sulfatoetyl sulfonicacid)-2methyl anthraquinone (2) and 1-amino-4-(5'-amino naphtalene-3'-sulfonic acid)-2-methyl anthraquinone (3) was prepared with a stirred mixture of $\mathrm{Pd}_{2}(\mathrm{dbap})_{3}$, BINAP and $\mathrm{Cs}_{2} \mathrm{CO}_{3}$ as per our previous work ${ }^{9}$.

\section{Preparation of the metal complexes}

$\mathrm{Fe}(\mathrm{III})$ and $\mathrm{Co}(\mathrm{II})$ complexes

The complexes of the ligand were prepared in ethyl alcohol as given in previous work ${ }^{9}$.

\section{Cr(III)complex}

3a (0.196 mmol, 23. $2 \mathrm{mg})$ was dissolved in DMF $(10 \mathrm{~mL})$ and added to $\mathrm{CrCl}_{3} \cdot 6 \mathrm{H}_{2} \mathrm{O}$ (0.062 mmol, $23.0 \mathrm{mg}$ ). NaOAc was added to the mixture and stirred at $5 \mathrm{~h}$ in room temperature and cooled. The solution was filtered and dried ${ }^{10}$.

4-(2'-Amino benzene sulfonic acid)azo-(2''-N-(4',',6','-dichloro s-triazine) benzene-5' '-( $\beta$-sulfatoetyl sulfonyl)-2-methyl anthraquinone (2a)

Ligand was obtained as a light brown powder in $75 \%$ yield. M.p. $211^{\circ} \mathrm{C}$. FT-IR $\left(\mathrm{KBr}, \mathrm{cm}^{-1}\right)$ : 3415, 1676, 1592, 1554, 1437, 1300, 1222, 1048, 791. UV-Vis (Ethanol nm): 252, 337, 480 \& (max): $3,95 \times 10^{3}$.

4-(2'-Amino benzene sulfonic acid)azo-(2',-N-(4',',6','-dichloro s-triazine) benzene-5' '-( $\beta$-sulfatoetyl sulfonyl)-2-methyl anthraquinone-Fe (2a-Fe)

Complex was obtained as an orange powder in $41 \%$ yield. M.p. $>300{ }^{\circ} \mathrm{C}$. FT-IR $\left(\mathrm{KBr}, \mathrm{cm}^{-1}\right)$ : 3316, 1673, 1590, 1551, 1437, 1304, 1262, 1068, 803, 577. UV-Vis (Ethanol nm): 246, 252, 276, 322, $482 \varepsilon(\max ): 4,52 \times 10^{4} .{ }^{1} \mathrm{H}$ NMR (DMSO-d6, ppm): 14.1(O-H). AAS:Calc (\%): 2.98, Found (\%): 3.18, $\mu_{\text {eff }}$ : 3.22 B.M. 
4-(2'-Amino benzene sulfonic acid)azo-(2',-N-(4',',6','-dichloro s-triazine) benzene-5' '-( $\beta$-sulfatoetyl sulfonyl)-2-methyl anthraquinone-Co (2a-Co)

Complex was obtained as a brick red powder in $62 \%$ yield. M.p. $>300{ }^{\circ} \mathrm{C}$. FT-IR $\left(\mathrm{KBr}, \mathrm{cm}^{-1}\right)$ : 3315, 1673, 1590, 1551, 1438, 1304, 1261, 1068, 802, 580. UV-Vis (Ethanol nm): 248, 325, $477 \varepsilon(\max ): 1,30 \times 10^{4}$. AAS: Calc(\%):3.19, Found(\%):2.85

4-(2'-Amino benzene sulfonic acid)azo-(2',-N-(4,',6','-dichloro s-triazine) naphtaline-5' '-sulfonic acid)-2-methyl anthraquinone (3a)

Ligand was obtained as a gray powder in $65 \%$ yield. M.p. $239,4{ }^{\circ} \mathrm{C}$. FT- IR $\left(\mathrm{KBr}, \mathrm{cm}^{-1}\right)$ : 3416, 1674, 1591, 1544, 1451, 1231, 1172, 1046, 796. UV-Vis (Ethanol, nm): 203, 228, 332, $463 \varepsilon$ (max): $6,32 \times 10^{2}$.

4-(2'-Amino benzene sulfonic acid)azo-(2''-N-(4',',6','-dichloro s-triazine) naphtaline-5',-sulfonic acid)-2-methyl anthraquinone-Fe (3a-Fe)

Complex was obtained as a black powder in $58 \%$ yield. M.p. $>300{ }^{\circ} \mathrm{C}$. FT- IR $\left(\mathrm{KBr}, \mathrm{cm}^{-1}\right)$ : 3413, 1722, 1611, 1589,1438, 1271, 1116, 1025, 772, 536. UV-Vis (Ethanol nm): 206, 235, 335, $471 \varepsilon(\max ): 1.0 \times 10^{3}$. AAS: Calc(\%):5.56, Found(\%):5.70

4-(2'-Amino benzene sulfonic acid)azo-(2''-N-(4',',6','-dichloro s-triazine) naphtaline-5' '-sulfonic acid)-2-methyl anthraquinone-Cr (3a-Cr)

Complex was obtained as a dark brown powder in $56 \%$ yield. M.p. $>300{ }^{\circ} \mathrm{C}$. FT-IR $\left(\mathrm{KBr}, \mathrm{cm}^{-}\right.$ $\left.{ }^{1}\right)$ : 3416, 1673, 1591, 1549, 1437, 1269, 1104, 1011, 799, 579. UV-Vis (Ethanol nm): 204, 250, 342, $443 \varepsilon(\max ): 8,78 \times 10^{4}$. AAS: Calc(\%):2.95, Found(\%):2.27, $\mu_{\text {eff }}: 2.36$ B.M.

\section{Antibacterial activity process}

Disc diffusion method ${ }^{11}$ with some modification was used to determine the antibacterial activity of the synthesized compounds. Bacillus subtilis B-354, Streptococcus epidermidis B4268, Escherichia coli B-4269, ARS (NRRL) (Agricultural Research Service Culture Collection), Staphylococcus aureus 29213 ATCC (American Type Culture Collection) and Escherichia coli K-12 were selected as test organisms. In addition, MRSA (MethicillinResistant Staphylococcus aureus) and C.D.(Corynebacterium diphtheriae) clinical isolate from patients were obtained from Cukurova University Medicine Faculty Balcali Hospital. The synthesized compounds were dissolved in dimethyl sulfoxide at concentrations of $10^{-3} \mathrm{M}$. Synthesized compound impregnated $(10 \mu \mathrm{L})$ onto a disc of filter paper was varied to study its effect on the growth test organisms. They were incubated at the $37^{\circ} \mathrm{C}$ for $24 \mathrm{~h}$. The antibacterial activity of dyed cotton and wool fabric specimens was tested. Cotton and wool fabric samples (1 cm diameter) were placed on the surface of the inoculated plates and diameter of the inhibition zone (mm) was measured after incubation. Antimicrobial activity of DMSO against the test organisms was also investigated, but was found to have no antimicrobial activity against any of the organisms. Ampicillin (30 $\mu \mathrm{g})$ was used as a standard antibiotic (S.A) for the antibacterial activities.

\section{Results and Discussion}

The mixed ligands, including azo, anthraquinone and s-triazine moieties were synthesized according to previous work ${ }^{9}$ (Figure 1 ). 2-Amino benzene sulfonic acid, 4-( $\beta$-sulfatoethyl sulfonyl) aniline and 5-amino naphthalene-3-sulfonic acid was used for this work (Table 1). The products were obtained in 56-75\% yield after purification. The obtained results are supported the proposed structures. 


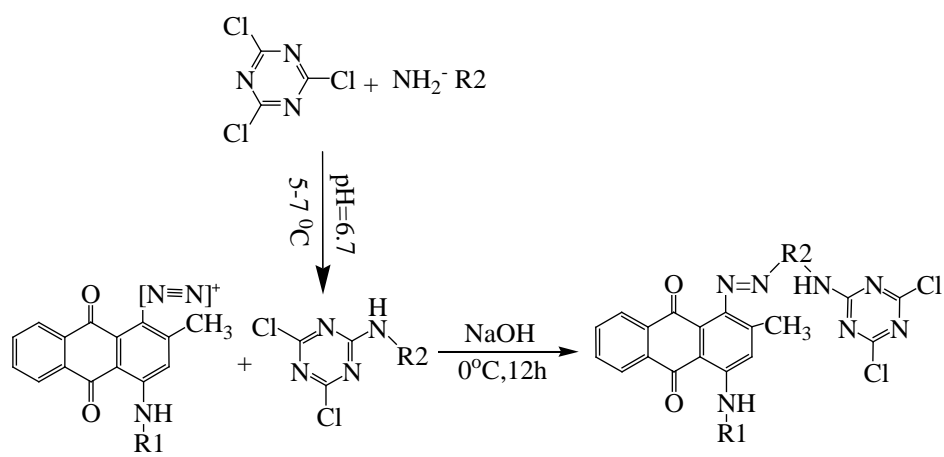

Figure 1. General coupling reaction for the synthesized azo compounds

\section{FT-Infrared spectra}

The primary amine asymmetric-symmetric stretching vibration bands at $3400-3200 \mathrm{~cm}^{-1}$ assigned to $v(\mathrm{~N}-\mathrm{H})$ which are belonging to the starting material, 1-amino-4-bromo-2-methyl anthraquinone vanished after diazotization and the sec-amine peaks were observed about $3400 \mathrm{~cm}^{-1}$ in the FT-IR spectra of the all ligands. Typically, 2a and 3a showed the peaks which assigned to $v(\mathrm{~S}=\mathrm{O})$ band between at $1104-1262 \mathrm{~cm}^{-1}, v(\mathrm{C}=\mathrm{N})$ band at $1544-1589 \mathrm{~cm}^{-1}$ and $v(\mathrm{Ar}-\mathrm{Cl})$ band between at $1011-1068 \mathrm{~cm}^{-1}$ in s-triazine group in Table $1 . v(\mathrm{~N}=\mathrm{N})$ and $v(C=O)$ stretching bonds belong to the ligands shifted from $1437-1451 \mathrm{~cm}^{-1}$ to $1437-1438 \mathrm{~cm}^{-1}$ and from $1676-1674 \mathrm{~cm}^{-1}$ to $1673 \mathrm{~cm}^{-1}$ in their metal complexes respectively. These shifts indicated coordination of carbonyl oxygen and azo group to the metal ions ${ }^{12,13}$. The new observing peaks between $536-580 \mathrm{~cm}^{-1}$ could be attributed to metal-oxygen bonds $v(\mathrm{M}-\mathrm{O})$ in the complexes ${ }^{14,15}$ as shown in Table 2.

Table 1. The synthesized compounds and binding functional groups

\begin{tabular}{|c|c|c|}
\hline \multirow[t]{2}{*}{ Compound } & \multicolumn{2}{|c|}{ Functional Groups } \\
\hline & R1 & R2 \\
\hline $2 a$ & $\mathrm{PhSO}_{2} \mathrm{CH}_{2} \mathrm{CH}_{2} \mathrm{OSO}_{3} \mathrm{H}$ & $\mathrm{PhSO}_{3} \mathrm{H}$ \\
\hline 3a & $\mathrm{NaphtSO}_{3} \mathrm{H}$ & $\mathrm{PhSO}_{3} \mathrm{H}$ \\
\hline
\end{tabular}

Table 2. Characteristic bands in the FT-IR spectra $\left(\mathrm{cm}^{-1}\right)$ of the synthesized compounds

\begin{tabular}{cccccccccc}
\hline Compound & $\mathrm{N}=\mathrm{N}$ & $\mathrm{N}-\mathrm{H}$ & $\mathrm{C}=\mathrm{N}$ & $\mathrm{Ar}-\mathrm{Cl}$ & $\mathrm{C}=\mathrm{C}$ & $\mathrm{C}=\mathrm{O}$ & $\mathrm{CH}_{3}$ & $\mathrm{~S}=\mathrm{O}$ & $\mathrm{M}-\mathrm{O}$ \\
\hline 2a & 1437 & 3415 & 1554 & 1048 & 1592 & 1676 & 1300 & 1222 & - \\
2a-Fe & 1437 & 3316 & 1551 & 1068 & 1590 & 1673 & 1304 & 1262 & 577 \\
2a-Co & 1438 & 3315 & 1551 & 1068 & 1590 & 1673 & 1304 & 1261 & 580 \\
3a & 1451 & 3416 & 1544 & 1046 & 1591 & 1674 & 1231 & 1172 & - \\
3a-Fe & 1438 & 3413 & 1589 & 1025 & 1611 & 1722 & 1271 & 1116 & 536 \\
3a-Cr & 1437 & 3416 & 1549 & 1011 & 1591 & 1673 & 1269 & 1104 & 579 \\
\hline
\end{tabular}

\section{UV-Visible spectra}

The electronic absorption spectra of the synthesized compounds was recorded at room temperature in EtOH as shown in Table 3. The peaks were observed at 482 and $477 \mathrm{~nm}$ for 2a-Fe, 2a-Co respectively. Their molar extinction coefficients at the wavelength of maximum absorption $\left(\lambda_{\text {peak }}\right)$ higher than all remain synthesized compounds. The increasing extinction coefficient of anthraquinone compounds indicates their good ability dyeing by chemical modifications ${ }^{16}$. The characteristic $n \rightarrow \pi^{*}$ transition peaks are observed between at 
322-342 nm for the azo compounds. Typically, in UV spectrum of $-\mathrm{N}=\mathrm{N}$ - group, the shoulder is assigned to $n \rightarrow \pi^{*}$ transition between at $323-347 \mathrm{~nm}^{17}$. When the metal attaches to the ligands, small amounts of their absorption intensities and shifts were observed ${ }^{15}$.

Table 3. UV Spectra of the synthesized compounds (Solvent Ethanol)

\begin{tabular}{ccccc}
\hline Compounds & $\lambda, \mathrm{nm} \pi \rightarrow \pi^{*}$ & $\lambda, \mathrm{nm}_{\mathrm{azo}} \mathrm{n} \rightarrow \pi^{*}$ & $\lambda, \mathrm{nm} \mathrm{n} \rightarrow \pi^{*}$ & $\varepsilon\left(\mathrm{Lmol}^{-1} \mathrm{~cm}^{-1}\right) \mathrm{max}$ \\
\hline 2a & 252 & 337 & 480 & $3,88 \times 10^{4}$ \\
2a-Fe & 252 & 322 & 482 & $4,52 \times 10^{4}$ \\
2a-Co & 248 & 325 & 477 & $1,30 \times 10^{4}$ \\
3a & 228 & 332 & 463 & $6,32 \times 10^{2}$ \\
3a-Fe & 235 & 335 & 471 & $1,00 \times 10^{3}$ \\
3a-Cr & 250 & 342 & 443 & $8,78 \times 10^{3}$ \\
\hline
\end{tabular}

${ }^{1} \mathrm{H}$ and ${ }^{13} \mathrm{C}$ NMR spectra

The NMR spectra of all compounds confirmed the expected structures. The samples measured in DMSO- $\mathrm{d}^{6}$ solvent at $25{ }^{\circ} \mathrm{C}$, in Table 4. The singlet signal at $\delta 2.4$ and $2.6 \mathrm{ppm}$ assigned to three protons $\left(-\mathrm{CH}_{3}\right)$, at $\delta 6.7-8.2 \mathrm{ppm}$ multiple peaks of two protons in the quinone ring. The value of a chemical shift for methyl group which is an electron donor moiety indicated shielding effect. The multiple signals belong to $\left(-\mathrm{C}_{2}\right)$ of vinylsulfone group appeared at $\delta 3.1-4.5 \mathrm{ppm}$. In the ${ }^{1} \mathrm{H}$ NMR spectra of ligands, the peak which is belonging to starting material, $\left(\mathrm{NH}_{2}\right)$ at $\delta 3.3 \mathrm{ppm}$ disappeared after the diazotization process. The singlet peak for the $(\mathrm{N}-\mathrm{H})$ binding s-triazine ring showed around at $\delta 10.2$ and $10.8 \mathrm{ppm}$ but another contribution was not observed by the heterocyclic structure which has not any proton as shown in Table $4^{13,17}$.

Table 4. The ${ }^{1} \mathrm{H}$ and ${ }^{13} \mathrm{C}$ NMR (400 MHz) spectral values of the synthesized compounds, 2a, 3a

Compds ${ }^{1} \mathrm{H}$ NMR $\left(\delta, \operatorname{ppm}, \mathrm{CDCI}_{3}, 25{ }^{\circ} \mathrm{C}\right) \quad{ }^{13} \mathrm{C}$ NMR $\left(\delta, \operatorname{ppm}, \mathrm{DMSO}, 25^{\circ} \mathrm{C}\right)$

$\delta 2.2\left(\mathrm{~s}, \mathrm{SO}_{3} \mathrm{H},-\mathrm{O} \underline{\mathrm{H}}\right), \delta 2.4\left(\mathrm{~s},-\underline{\mathrm{C}}_{3}\right), \delta$

2a 3.1-4.5 (- $\left.\underline{\mathrm{C}}_{2}\right), \delta$ 6.9-8.2 (m, 9H, Ph), $\delta$

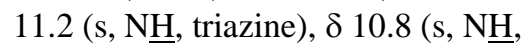
$\mathrm{Ph}-\mathrm{N} \underline{\mathrm{H}}-\mathrm{Ph}), \mathrm{ppm}$.

$\delta 18.0\left(-\mathrm{CH}_{3}\right), \delta 119.0-150.0(\mathrm{C}$, aromatic), $\delta 143$ (C-N=N-Ph), $\delta 145$

$(\mathrm{Ph}-\mathrm{N}=\mathrm{N}-\mathrm{C}), \delta 154(\mathrm{NH}-\mathrm{C}-\mathrm{N}-$ (triazine)), $\delta 162(\mathrm{~N}-\mathrm{C}(\mathrm{Cl})-\mathrm{N}-$ (triazine)), $\delta 181(\underline{\mathrm{C}}=\mathrm{O}) \mathrm{ppm}$. $\delta 21.2\left(-\mathrm{CH}_{3}\right), \delta 118.0-151.0(\mathrm{C}$, $\left.\delta 1.9\left(\mathrm{SO}_{3} \mathrm{H},-\mathrm{OH}\right), \delta 2.6\left(\mathrm{~s},-\mathrm{CH}_{3}\right), \delta\right), \delta$ $3 a$ 6.7-8.2 (m, 9H, Ph), $\delta 11.2(\mathrm{~N} \underline{\mathrm{H}}$, aromatic), $\delta 140$ (NH-C(Ph), $\delta 146$ (ㄷ$\mathrm{N}=\mathrm{N}-\mathrm{Ph}), \delta 150(\mathrm{Ph}-\mathrm{N}=\mathrm{N}-\mathrm{C}), \delta 152$

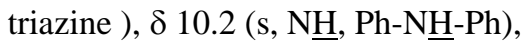
ppm.

(NH-C-N- (triazine)), $\delta 162(\mathrm{~N}-\mathrm{C}(\mathrm{Cl})-$ $\mathrm{N}$ - (triazine)), $\delta 187(\underline{\mathrm{C}}=\mathrm{O}) \mathrm{ppm}$.

The carbon peaks belong to $\left(\mathrm{CH}_{3}\right)$ group bonding anthraquinone was measured in the range $\delta 18-21 \mathrm{ppm}$ as singlet in all the ligands. The aromatic carbons belong to anthraquinone ring gave multiple signals near $\delta$ 118-151 ppm. Furthermore, the peaks between at $\delta 145-146$ were assigned to $(\mathrm{C}-\mathrm{N}=\mathrm{N}-\mathrm{Ph})$. The carbon peaks of s-triazine were observed at $\delta$ 152-154 (NH- $\underline{\mathrm{C}}-\mathrm{N}$ - (triazine)). Typically, the signals of carbonyl units $(\underline{\mathrm{C}}=\mathrm{O})$ which are common in all the ligands on a ketone group gave in the range $\delta 181-187 \mathrm{ppm}$ as singlet ${ }^{3,18,19}$. 


\section{Atomic absorption spectra and magnetic susceptibilities}

The calculations of metal percentages showed the mole ratios were estimated as 2:1 and 1:1 for the metal complexes as given in experimental section. These values were supported by the obtained results of Job's method. The synthesized metal complexes which have octahedral geometry include one and two chloride atoms in their outer sphere the resultant of argentometric titration data for the complexes of $\mathbf{2 a}$ and $\mathbf{3 a}$ respectively ${ }^{20}$, as shown in Figure 2.<smiles>[R1]Nc1cc(C)c(N=NC([R1])Nc2nc(Cl)nc(Cl)n2)c2c1C(=O)c1ccccc1C2=O</smiles>

a) $\mathrm{M}: \mathrm{Fe}(\mathrm{III}) \quad(\mathbf{n}=3, \mathbf{m}=1)$
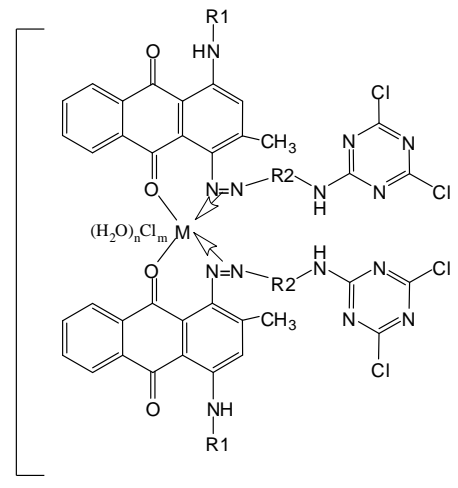

b) $\mathrm{M}$ : $\mathrm{Fe}(\mathrm{III}), \mathrm{Cr}(\mathrm{III}), \mathrm{Co}(\mathrm{II})(\mathbf{n}=0-1, \mathbf{m}=1-2)$

Figure 2. Plausible structures for the synthesized metal complexes (L:M), a) 1:1 b) 2:1 ratios (coordination number 6)

The magnetic moment of 2a-Fe was measured as $3.22 \mathrm{BM}$ and indicated the low spin complex Fe(III) state in room temperature. The magnetic interaction between ligand and metal caused a deviation in magnetic susceptibility value ${ }^{21}$. 3a-Cr was determined as 2.36 BM for $\mathrm{d}^{1}$ electron configuration. The mononuclear complexes exhibited the strong field ligand effects ${ }^{22,23}$.

\section{Antibacterial activities}

Escherichia coli, is a gram-negative bactera, Staphylococcus aureus, Bacillus subtilis, Streptococcus epidermidis and Corynebacterium diphtheriae, are gram-positive bacteria, and was test bacteria. Staphylococcus aureus is the major cause of cross-infection in hospitals, and it is the most frequently evaluated species. The results of antimicrobial screening of the synthesized compounds, metal salts and standard antibiotic are given in Table 5 and 7 respectively. Only one compound (3a-Fe) showed activity while other showed no activity. MRSA used in the present study are responsible for many hospital infections. The antibacterial activities of compounds against MRSA strains and C.D. are shown in Table 6 and 8, which indicates the antibacterial activity is strengthened metal containing compounds on MRSA. Among the Fe-complex series of compounds tested, 2a-Fe was found active against only one C.D. The same compounds were also tested against MRSA, but there was not any activity detected. However, among Fe-complex compounds, 3a-Fe affected all MRSA and Staphylococcus aureus. 3a-Cr compound was showing the same antimicrobial activity as 2aFe compound. 3a from synthesized compounds was found active against three MRSA strains. In particular, synthesized compounds with metal complex showed more bacterial activity than the others against these strains. It is obvious that antibacterial properties are closely related to the dye structure, especially the presence of functional groups on $i^{24}$. The similar results indicate that the synthesized compounds can inactivate both gram-negative and gram-positive bacteria effectively ${ }^{25}$. Remaining compounds exhibited no antibacterial activity at all. The zone of bacterial inhibition was not found for DMSO. 
Table 5. Antibacterial activities of compounds on standard bacteria

\begin{tabular}{|c|c|c|c|c|c|}
\hline & $\begin{array}{c}\text { Escherichia } \\
\text { coli } \\
\mathrm{K}-12 \\
\end{array}$ & $\begin{array}{c}\text { Bacillus } \\
\text { subtilis } \\
\text { B-354 } \\
\end{array}$ & $\begin{array}{c}\text { Escherichia } \\
\text { coli } \\
\text { B-4269 } \\
\end{array}$ & $\begin{array}{c}\text { Streptococcus } \\
\text { epidermidis } \\
\text { B-4268 }\end{array}$ & $\begin{array}{c}\text { Staphylococcus } \\
\text { aureus } \\
29213 \\
\end{array}$ \\
\hline $\begin{array}{l}\text { Metal salts } \\
\text { Ligands }\end{array}$ & 0 & 0 & 0 & 0 & 0 \\
\hline $2 \mathrm{a}$ & 0 & 0 & 0 & 0 & 0 \\
\hline $\begin{array}{l}3 \mathrm{a} \\
\mathrm{Fe}^{2+}\end{array}$ & 0 & 0 & 0 & 0 & 0 \\
\hline 2a-Fe & 0 & 0 & 0 & 0 & 0 \\
\hline $\begin{array}{l}\text { 3a-Fe } \\
\mathrm{Co}^{2+}\end{array}$ & 0 & 0 & 0 & 0 & 9 \\
\hline $\begin{array}{l}\text { 2a-Co } \\
\mathrm{Cr}^{6+}\end{array}$ & 0 & 0 & 0 & 0 & 0 \\
\hline 3a-Cr & 0 & 0 & 0 & 0 & 0 \\
\hline DMSO & 0 & 0 & 0 & 0 & 0 \\
\hline S.A. & 22 & 24 & 19 & 21 & 0 \\
\hline
\end{tabular}

Table 6. Antibacterial activities of compounds on MRSA and C.D

\begin{tabular}{|c|c|c|c|c|c|c|c|c|c|c|c|c|}
\hline & $\begin{array}{c}\text { MRSA } \\
02 \\
\end{array}$ & $\begin{array}{c}\text { MRSA } \\
03 \\
\end{array}$ & $\begin{array}{c}\text { MRSA } \\
09 \\
\end{array}$ & $\begin{array}{c}\text { MRSA } \\
38 \\
\end{array}$ & $\begin{array}{c}\text { MRSA } \\
59 \\
\end{array}$ & $\begin{array}{c}\text { MRSA } \\
87 \\
\end{array}$ & $\begin{array}{c}\text { MRSA } \\
313 \\
\end{array}$ & $\begin{array}{c}\text { MRSA } \\
12 \\
\end{array}$ & $\begin{array}{c}\text { MRSA } \\
13 \\
\end{array}$ & $\begin{array}{c}\text { MRSA } \\
57 \\
\end{array}$ & $\begin{array}{l}\text { C.D. } \\
557 \\
\end{array}$ & $\begin{array}{r}\text { C.D. } \\
111 \\
\end{array}$ \\
\hline $\begin{array}{l}\text { Metal } \\
\text { salts }\end{array}$ & 0 & 0 & 0 & 0 & 0 & 0 & 0 & 0 & 0 & 0 & 0 & 0 \\
\hline Ligands & & & & & & & & & & & & \\
\hline 2a & 0 & 0 & 0 & 0 & 0 & 0 & 0 & 0 & 0 & 0 & 0 & 0 \\
\hline $\begin{array}{c}3 \mathrm{a} \\
\mathrm{Fe}^{2+}\end{array}$ & 0 & 0 & 8 & 7 & 0 & 0 & 0 & 0 & 0 & 9 & 0 & 0 \\
\hline 2a-Fe & 0 & 0 & 0 & 0 & 0 & 0 & 0 & 0 & 0 & 0 & 7 & 0 \\
\hline $\begin{array}{l}\text { 3a-Fe } \\
\mathrm{Co}^{2+}\end{array}$ & 8 & 9 & 9 & 9 & 9 & 9 & 7 & 9 & 8 & 9 & 0 & 0 \\
\hline 2a-Co & 0 & 0 & 0 & 0 & 0 & 0 & 0 & 0 & 0 & 0 & 0 & 0 \\
\hline 3a-Cr & 0 & 0 & 0 & 0 & 0 & 0 & 0 & 0 & 0 & 0 & 8 & 0 \\
\hline DMSO & 0 & 0 & 0 & 0 & 0 & 0 & 0 & 0 & 0 & 0 & 0 & 0 \\
\hline S.A. & 0 & 0 & 0 & 0 & 0 & 0 & 0 & 0 & 0 & 0 & 18 & 18 \\
\hline
\end{tabular}

Table 7. Antibacterial activities of compounds on standard bacteria at concentrations of $10^{-3} \mathrm{M}$

\begin{tabular}{lccccc}
\hline & $\begin{array}{c}\text { Escherichia } \\
\text { coli K-12 }\end{array}$ & $\begin{array}{c}\text { Bacillus } \\
\text { subtilis } \\
\text { B-354 }\end{array}$ & $\begin{array}{c}\text { Escherichia } \\
\text { Coli B-4269 }\end{array}$ & $\begin{array}{c}\text { Streptococcus } \\
\text { epidermidis } \\
\text { B-4268 }\end{array}$ & $\begin{array}{c}\text { Staphylococcus } \\
\text { aureus 29213 }\end{array}$ \\
\hline $\begin{array}{l}\text { Metal salts } \\
\text { Ligands }\end{array}$ & 0 & 0 & 0 & 0 & 0 \\
3a & 0 & 0 & 0 & 0 & 0 \\
$\mathrm{Fe}^{2+}$ & & & & & \\
2a-Fe & 0 & 9 & 0 & 0 & 9 \\
3a-Fe & 0 & 9 & 0 & 0 & 9 \\
$\mathrm{Cr}^{6+}$ & 0 & 7 & 0 & 0 & 0 \\
3a-Cr & 0 & 0 & 0 & 0 & 0 \\
DMSO & 0 & 24 & 19 & 21 & 0 \\
S.A. & 22 & & & & \\
\hline
\end{tabular}


Table 8. Antibacterial activities of compounds on MRSA and C.D. at concentrations of $10^{-3} \mathrm{M}$

\begin{tabular}{|c|c|c|c|c|c|c|c|c|c|c|c|c|}
\hline & \multicolumn{4}{|c|}{ MRSA MRSA MRSA MRSA } & \multicolumn{2}{|c|}{ MRSA MRSA } & \multirow{2}{*}{$\begin{array}{c}\text { MRSA } \\
313\end{array}$} & \multicolumn{2}{|c|}{ MRSA MRSA } & \multirow{2}{*}{$\begin{array}{c}\text { MRSA } \\
57\end{array}$} & \multirow{2}{*}{$\begin{array}{l}\text { C.D. } \\
557\end{array}$} & \multirow{2}{*}{$\begin{array}{l}\text { C.D. } \\
111 \\
\end{array}$} \\
\hline & 02 & 03 & 09 & 38 & 59 & 87 & & 12 & 13 & & & \\
\hline $\begin{array}{c}\text { Metal } \\
\text { salts }\end{array}$ & 0 & 0 & 0 & 0 & 0 & 0 & 0 & 0 & 0 & 0 & 0 & 0 \\
\hline Ligands & & & & & & & & & & & & \\
\hline $\begin{array}{c}3 \mathrm{a} \\
\mathrm{Fe}^{2+}\end{array}$ & 7 & 8 & 0 & 0 & 0 & 0 & 0 & 0 & 0 & 0 & 0 & 0 \\
\hline $2 \mathrm{a}-\mathrm{Fe}$ & 7 & 8 & 9 & 10 & 7 & 0 & 9 & 9 & 7 & 8.5 & 0 & 0 \\
\hline $\begin{array}{c}3 \mathrm{a}-\mathrm{Fe} \\
\mathrm{Cr}^{6+}\end{array}$ & 9 & 9.5 & 10 & 9.5 & 10 & 0 & 10.5 & 10 & 9.5 & 11.5 & 0 & 11 \\
\hline 3a-Cr & 0 & 0 & 7 & 7 & 7 & 0 & 0 & 0 & 0 & 0 & 0 & 0 \\
\hline DMSO & 0 & 0 & 0 & 0 & 0 & 0 & 0 & 0 & 0 & 0 & 0 & 0 \\
\hline S.A. & 0 & 0 & 0 & 0 & 0 & 0 & 0 & 0 & 0 & 0 & 18 & 18 \\
\hline
\end{tabular}

Many of the phyto origin anthraquinones compounds are affected to Pseudomonas aeruginosa $^{26}$, Bacillus subtilis, Escherichia coli, Micrococcus luteus ${ }^{27}$. In this study, synthesized compounds were showing no antibacterial activity againts gram-negative bacterium Escherichia coli. The antimicrobial activities of quinones may be linked to their properties to be complex irreversibly with nucleophilic amino acids in proteins often leading to inactivation of the protein and loss of biological function ${ }^{28}$.

\section{Conclusion}

In this work, we have prepared new mixed ligand materials composed of $\mathrm{Cr}(\mathrm{III}), \mathrm{Fe}(\mathrm{III})$ and $\mathrm{Co}(\mathrm{II})$-substituted s-triazine and primer amine compounds as inorganic building blocks and 1-amino-4-bromo-2-methyl anthraquinone as the organic ligand. The structures of the synthesized compounds were characterized with UV-visible, FT-IR, ${ }^{13} \mathrm{C}$ and ${ }^{1} \mathrm{H}$ NMR, AAS, magnetic susceptibility and argentometric titration techniques. Single crystals of the synthesized compounds could not be isolated from any solution; thus no definite structure may be described. However, our proposed structural formula is given in Figure 1 and 2. The octahedral structures were supported by using characterization techniques. The divalent Co complexes, trivalent iron and chromium complex exhibited as 2:1 and 1:1 molar ratio. They have one and two chloride atoms in their outer sphere according to argentometric methods for the metal complexes of $\mathbf{2 a}$ and $3 \mathbf{a}$ respectively.

As a result, the synthesized compounds were determined more active against MRSA strains, especially the values belong to 3a-Fe indicated that it could be used to prevent the infection although the merely metal salts have not any protective properties significantly. Therefore, the results obtained in this study can be accepted as promising new antibacterial agent compounds on MRSA.

\section{Acknowledgment}

The authors thank to TUBITAK, TBAG 107 T409 for financial supported.

\section{References}

1. Singh K, Singh S and Taylor J A, Dyes Pigments, 2002, 54, 189.

2. $\quad$ Peters A T and Chao Y C, J Soc Dyers Colour, 1988, 104, 435.

3. Wang S, Shen S and Xu H, Dyes Pigments, 2000, 44, 195-198. 
4. Kar P, Suresh M, Kumar D K, Jose D A Ganguly B and Das A, Polyhedron, 2007, 26, 1317.

5. Ferreira J, Santos M J L, Matos R, Ferreira O P, Rubira A F, Girotto E M, J Electroanal Chem., 2006, 591, 27-32.

6. Wu S, Qian W, Xia Z, Zou Y, Wang S, Shen S and Xu H, Chem Phys Lett., 2000, 330, 535-540.

7. Ma M, Sun Y and Sun G, Dyes Pigments, 2003, 58, 27-35.

8. Liu J and Sun G, Dyes Pigments, 2008, 77(2), 380-386.

9. Yildiz E, Cetinkol T and Serindag O, Synth React Inorg Met Org Nano- Met Chem., 2010, 40, 19.

10. Moriuchi T, Watanabe T, Ikeda I, Ogawa A and Hirao T, Eur J Inorg Chem., 2001, 1, 277.

11. Bauer A W, Kirby W M M, Sherris J C and Turck M, Am J Clin Pathol., 1966, 45, 493.

12. Ashok K, Mishra J and Jacob K M, Dyes Pigments, 2007, 75, 1-10.

13. Baqi Y, Weyler S, Iqbal J, Zimmermann H and Muller C E, Purinergic Signal., 2009, 5, 91-106.

14. Huang F, Wu Y, Gu D and Gan F, Spectrochimica Acta Part A, 2005, 61(13-14), 2856-2860.

15. Gup R, Giziroglu E and Kirkan B, Dyes Pigments, 2007, 73(1), 40-46.

16. Zollinger H, Color Chemistry, Wiley, Germany, Chapter, 2003, 637, 1, 2003.

17. Erdik E, Organik Kimyada Spektroskopik Yöntemler, Gazi Kitabevi, Ankara, 1998.

18. Refat M S, El-Korashy S A, Kumar D N and Ahmed A S, Spectrochimica Acta Part A, 2008, 70, 898-906.

19. Gaber M, Issia R M, Aly F A and Ayad M I, Thermochim Acta, 1989, 155, 309-316.

20. Jaglicic Z, Segedin P J and Zlatic J, J Magn Magn Mater., 2007, 310, 1444-1446.

21. Ruiz R, Lloret F, Julve M, Faus J, Munoz Mc and Solan X, Inorg Chim Acta, 1993, 213, 261.

22. Baligar R S and Revankar V K, Transition Met Chem., 2008, 33,361.

23. Georgousis Z D, Christidis P C, Litina D H and Bolos C A, J Mol Struct., 2007, 837, 30.

24. Singha R, Jainb A and Panwarb S, Guptab D and Kharea S, Dyes Pigments, 2005, 66, 99.

25. Liu J and Sun G, Dyes Pigments, 2008, 77, 380.

26. Lenta B N, Weniger B and Antheaume C, Noungoue D T, Ngouela S, Assob J C N, Vonthron-Senecheau C, Fokou P A, Devkota K P, Tsamo E and Sewald N, Phytochemistry, 2007, 68, 1595.

27. Xiang W, Song Q S, Zhang H J and Guo S P, Fitoterapia, 2008, 79, 501-504.

28. Cowan M M, Clinical Microbiology Reviews, 1999, 12, 564-582. 